(c) American Dairy Science Association, 2003.

\title{
Purification and Partial Characterization of Psychrotrophic Serratia marcescens Lipase
}

\author{
Adham M. Abdou \\ Department of Food Hygiene, Faculty of Veterinary Medicine, \\ Benha University, Moshtohor 13736 \\ Kaliobyia, Egypt
}

\section{ABSTRACT}

Serratia marcescens isolated from raw milk was found to produce extracellular lipase. The growth of this organism could contribute to flavor defects in milk and dairy products. Serratia marcescens was streaked onto spirit blue agar medium, and lipolytic activity was detected after $6 \mathrm{~h}$ at $30^{\circ} \mathrm{C}$ and after $12 \mathrm{~h}$ at $6^{\circ} \mathrm{C}$. The extracellular crude lipase was collected after inoculation of the organism into nutrient broth and then into skim milk. The crude lipase was purified to homogeneity by ion-exchange chromatography and gel filtration. The purified lipase had a final recovered activity of $45.42 \%$. Its molecular mass was estimated by SDSPAGE assay to be $52 \mathrm{kDa}$. The purified lipase was characterized; the optimum $\mathrm{pH}$ was likely between 8 and 9 and showed about $70 \%$ of its activity at $\mathrm{pH}$ 6.6. The enzyme was very stable at $\mathrm{pH} 8$ and lost about $30 \%$ of its activity after holding for $24 \mathrm{~h}$ at $4^{\circ} \mathrm{C}$ in buffer of $\mathrm{pH}$ 6.6. The optimum temperature was observed at $37^{\circ} \mathrm{C}$ and exhibited high activity at $5^{\circ} \mathrm{C}$. The thermal inactivation of $S$. marcescens lipase was more obvious at $80^{\circ} \mathrm{C}$; it retained about $15 \%$ of its original activity at $80^{\circ} \mathrm{C}$ and was completely inactivated after heating at $90^{\circ} \mathrm{C}$ for $5 \mathrm{~min}$. Under optimum conditions, activity of the enzyme was maximum after $6 \mathrm{~min}$. The Michaelis-Menten constant was $1.35 \mathrm{~m} M$ on tributyrin. The enzyme was inhibited by a concentration more than $6.25 \mathrm{mM}$. Purified lipase was not as heat-stable as other lipases from psychrotrophs, but it retained high activity at $5^{\circ} \mathrm{C}$. At $\mathrm{pH}$ 6.6, the $\mathrm{pH}$ of milk, purified lipase showed some activity and stability. Also, the organism demonstrated lipolytic activity at $6^{\circ} \mathrm{C}$ after $12 \mathrm{~h}$. Therefore, S. marcescens and its lipase were considered to cause flavor impairment during cold storage of milk and dairy products.

Received May 9, 2001.

Accepted May 11, 2002

Corresponding author: A. M. Abdou; e-mail: dradham@yahoo.com.

Current address: Minami-Ku, Kisshoin-Ishihara, Donoato-Nishimachi, Pharma Foods Int'l Co., Ltd., Research Department, Kyoto, Japan 601-8357.
(Key words: lipolytic activity, lipase enzyme, psychrotroph, Serratia marcescens)

\section{INTRODUCTION}

Psychrotrophic microorganisms in milk are important because they cause spoilage by altering the constituents of milk (Cousin, 1982). During growth at low temperature, many strains produce lipases and proteases that may adversely influence the quality and shelf life of most dairy products (Griffiths et al., 1981; Fox and Stepaniak, 1983; Stepaniak and Fox, 1985; Fairbairn and Law, 1986). The most frequently encountered psychrotrophs are the gram-negative genera, and Pseudomonas fluorescens is considered to be the most common species (Mikolajcik, 1979; Cousin, 1982).

Lipases from psychrotrophs, even at low concentration, can hydrolyze milk lipid and cause the rancid flavor in milk and dairy products that make these foods unacceptable to consumers (Deeth and Fitzgerald, 1976; Downey, 1980; Cousin, 1982; Shah, 1994). Extracellular lipases produced by psychrotrophs can withstand heat treatment of milk (Garcia et al., 1989) and may cause rancidity in UHT milk products during storage (Adams et al., 1975). Lipase production by psychrotrophs varies with the species, as does the optimum temperature, optimum $\mathrm{pH}$, and enzyme specificity (Thomas and Thomas, 1973). Reports that describe purification and characterization are focused mainly on enzymes secreted by Pseudomonas species. Relatively few studies deal with enzymes secreted by other genera (Alichanidis, 1988).

Ray (1996) described Serratia species as gram-negative psychrotrophs that were able to grow and produce heat-stable extracellular lipase and protease during the refrigerated storage of foods. The early literature reported that $S$. marcescens has been isolated as a psychrophilic microorganism from raw milk (Thomas, 1958; Witter, 1961). Recently, some workers have isolated psychrotrophs from refrigerated raw milk samples; about 3 to $6 \%$ of the isolated strains were $S$. marcescens (Milliere and Veillet-Poncet, 1985; Ahmed et al., 1989; Abdou, 1997). Serretia marcescens was found to 
have lipolytic and proteolytic activities (Abdou and Ohashi, 1996).

Many reviews have described in some detail the isolation and properties of lipases from psychrotrophs; however, few studies have dealt with the factors affecting lipase production. Henriette et al. (1993) studied the effect of culture conditions on lipolytic production by $S$. marcescens; at $22^{\circ} \mathrm{C}$ the microorganism grew exponentially for approximately $6 \mathrm{~h}$ before entering the stationary growth phase, and the cells excreted their lipases during the stationary phase. Makhzoum et al. (1995) showed that lipase production began after about 5 to $10 \mathrm{~h}$ at $27^{\circ} \mathrm{C}$.

Information on extracellular lipase produced by Serratia species is particularly limited, although some strains have been isolated from raw milk. Therefore, the objectives in this study were to focus on the lipolytic activity of $S$. marcescens and the purification and partial characterization of its extracellular lipase.

\section{MATERIALS AND METHODS}

\section{Organism}

During our study of psychrotrophic microorganisms (Abdou and Ohashi, 1996), psychrotrophic S. marcescens was originally isolated from raw milk, maintained on nutrient agar slope at $25^{\circ} \mathrm{C}$, and stored at $4^{\circ} \mathrm{C}$.

\section{Lipolytic Activity on Media}

Serratia marcescens was streaked onto spirit blue agar medium and lipase reagent (Difco Laboratories, Detroit, MI), and the plates were incubated at 6,17 , and $30^{\circ} \mathrm{C}$ for up to $14 \mathrm{~d}$. The plates were observed after $6 \mathrm{~h}$ and every $12 \mathrm{~h}$ for the clearing of the blue or deep blue color around each streak (Marshall, 1992). Lipolytic activities of $S$. marcescens, at different degrees of temperature, were compared by measuring the width (millimeters) of areas of clearing or areas of deep blue color around the colonies.

\section{Preparation of Crude Enzyme}

Serratia marcescens was subcultured on nutrient agar slopes and then in nutrient broth at $30^{\circ} \mathrm{C}$ for $24 \mathrm{~h}$. Aliquots of $150 \mu 1$ were inoculated into 15 -ml portions of sterile $10 \%$ reconstituted skim milk (Kumura et al., 1991) and incubated at $30^{\circ} \mathrm{C}$ for $3 \mathrm{~d}$, followed by incubation at $6^{\circ} \mathrm{C}$ for another $3 \mathrm{~d}$. These portions were centrifuged at $20,000 \times g$ at $4^{\circ} \mathrm{C}$ for $30 \mathrm{~min}$. The supernatants were filtered using $0.45-\mu \mathrm{m}$ cellulose acetate filter units (Toyo Roshi Kaisha, Ltd., Japan). The filtrates were used as the crude enzyme in the following experiments.

\section{Measurement of Lipase Activity}

Activities of the crude lipase and chromatographic fractions were determined by the method of Saito (1979), except that the substrate was tributyrin emulsion (Fox and Stepaniak, 1983) composed of $2 \%$ gum arabic, $0.4 M \mathrm{NaCl}$, and $5 \mathrm{mM} \mathrm{CaCl} \mathrm{Cl}_{2}$ blended for $2 \mathrm{~min}$ at $50^{\circ} \mathrm{C}$ with the appropriate concentration of tributyrin in the suitable buffer. A quantity $(0.3 \mathrm{ml})$ of the enzyme preparation was added to $2 \mathrm{ml}$ of the substrate solution in glass-stoppered test tubes that had been preincubated in a water bath at $37^{\circ} \mathrm{C}$ for $6 \mathrm{~min}$ at $\mathrm{pH} 8$. The mixture was held for $10 \mathrm{~min}$ at $37^{\circ} \mathrm{C}$. The enzymatic reaction was terminated by adding $7.5 \mathrm{ml}$ of the extraction reagent (isopropane, $100 \mathrm{ml}$; heptane, $100 \mathrm{ml} ; 1 \mathrm{~N}$ $\mathrm{H}_{2} \mathrm{SO}_{4}, 8 \mathrm{ml}$ ). After vigorous shaking for $2 \mathrm{~min}$ and standing for $1 \mathrm{~h}$, the upper layer obtained was mixed with the color reagent (water $1 \mathrm{ml}$, phenol red $5 \mathrm{mg}$, Na-barbital $25 \mathrm{mg}$, ethanol $200 \mathrm{ml}$ ), and shaken for 30 $\mathrm{s}$. The absorbance was measured at the wavelength of $420 \mathrm{~nm}$ (double-beam spectrophotometer UV-190', Shimadzu Corporation, Kyoto, Japan). Optimum assay conditions (activity calculated as 100\% activity) were 2 $\mathrm{ml}$ of $2 \%$ tributyrin emulsion mixed with $0.3 \mathrm{ml}$ of lipase preparation maintained at $37^{\circ} \mathrm{C}$ in buffer of $\mathrm{pH} 8$ for 6 min. One lipase unit activity was defined as the $\mu$ moles of liberated free fatty acid $/ \mathrm{min}$ at $37^{\circ} \mathrm{C}$. Palmitic acid was used as a standard fatty acid. The results obtained were means of triplicates for each experiment.

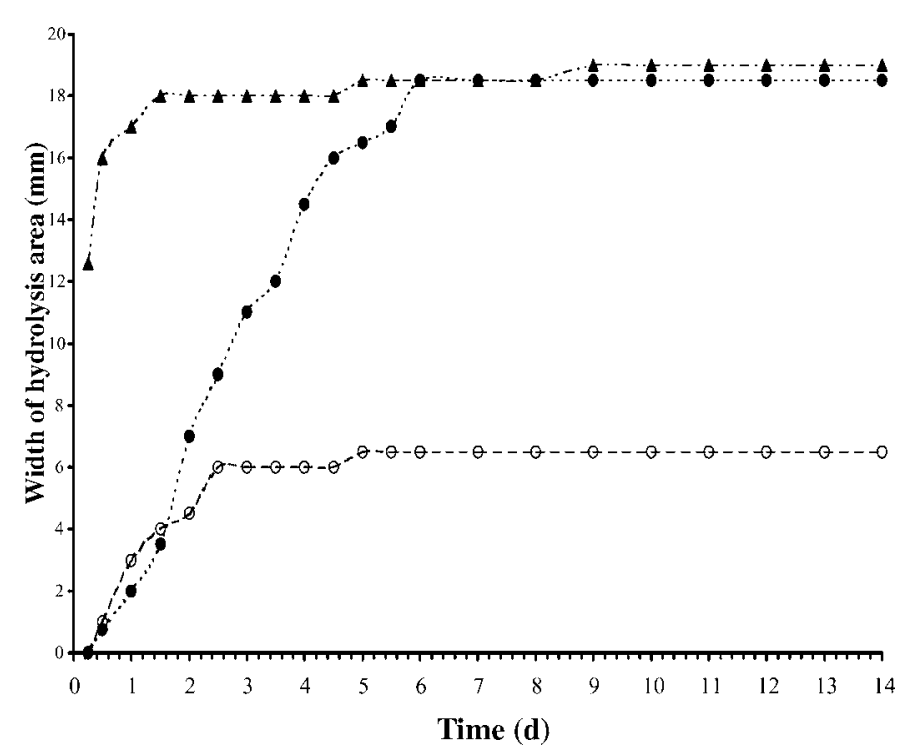

Figure 1. Lipolytic activities of Serratia marcescens at different temperatures on spirit blue agar media (Difco Laboratories, Detroit, $\mathrm{MI})$. Width of hydrolysis area $(\mathrm{mm})$ at $6^{\circ} \mathrm{C}(\bullet)$, at $17^{\circ} \mathrm{C}(\mathrm{o})$, and at $30^{\circ} \mathrm{C}(\mathbf{\Delta})$. 


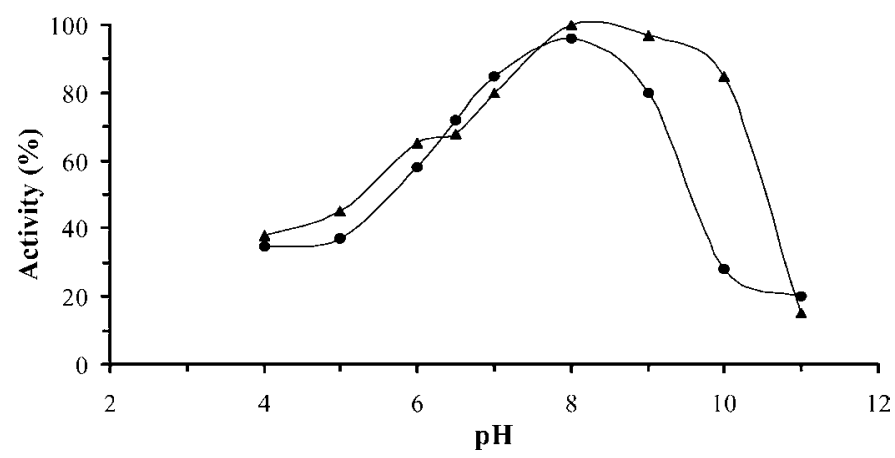

Figure 2. Effect of $\mathrm{pH}$ on Serratia marcescens purified lipase. Optimum $\mathrm{pH}$ for lipase on $2 \%$ tributyrin in universal buffers at $\mathrm{pH}$ 4 to 11 at $37^{\circ} \mathrm{C}(\mathbf{\Delta})$. Stability of lipase held for $24 \mathrm{~h}$ in universal buffers $\mathrm{pH} 4$ to 11 at $4^{\circ} \mathrm{C}(\mathbf{\bullet})$

\section{Measurement of Protein Concentration}

The protein concentration was determined by the method of Bradford (1976) using BSA (Sigma Chemical Co., St. Louis, MO) as the standard.

\section{Purification Procedures}

Step 1: CM-cellulose chromatography. The crude enzyme was first applied to a column $(20 \times 2.5 \mathrm{~cm})$ of CM-cellulose (Sigma Chemical Co.), which was preequilibrated with $10 \mathrm{~m} M$ sodium phosphate buffer $\mathrm{pH}$ 7.5. The lipase was allowed to bind to the gel for $2 \mathrm{~h}$ at $4{ }^{\circ} \mathrm{C}$ and was eluted with a linear gradient of Triton $\mathrm{X}-100(0$ to $1 \% ; 200 \mathrm{ml})$. The flow rate was $60 \mathrm{ml} / \mathrm{h}$, and fractions of $5 \mathrm{ml}$ were collected.

Step 2: DEAE-cellulose chromatography. The lipase-rich fractions were pooled and applied to a column $(15 \times 1.5 \mathrm{~cm})$ of DEAE-cellulose (Sigma Chemical Co.), which was pre-equilibrated with $10 \mathrm{~m} M$ sodium phosphate buffer at $\mathrm{pH}$ 7.5. The lipase was allowed to bind to the gel for $1 \mathrm{~h}$ at $4^{\circ} \mathrm{C}$. The column was washed thoroughly with the same buffer to remove unabsorbed material, which included Triton X-100 and was eluted with a linear gradient of $\mathrm{NaCl}(0.05$ to $1 M ; 300 \mathrm{ml})$ in the same buffer at a flow rate of $40 \mathrm{ml} / \mathrm{h}$. The eluate was collected in 5 -ml fractions.

Step 3: gel filtration. The concentrate was then applied to a column $(100 \times 2.5 \mathrm{~cm})$ of Sephadex G-150 (Pharmacia Fine Chemicals, Uppsala, Sweden), which was pre-equilibrated with $10 \mathrm{~m} M$ sodium phosphate buffer $\mathrm{pH} 7.5$ and eluted with the same buffer. The lipase-rich fractions were pooled, stored at $2^{\circ} \mathrm{C}$, and used as the purified lipase.

\section{Characterization of the Purified Lipase}

Optimum pH. Tributyrin emulsions (Fox and Stepaniak, 1983) were prepared in universal buffers (Stauf- fer, 1989) covering the $\mathrm{pH}$ range 4 to 11 . The enzyme was diluted in the buffers and assayed separately in each substrate emulsion of the same $\mathrm{pH}$.

pH stability. Portions of the purified lipase were held at $4^{\circ} \mathrm{C}$ for $24 \mathrm{~h}$ in universal buffers for use at $\mathrm{pH}$ 4 to 11 . The described assay was carried out for each lipase portion to obtain its stability.

Optimum temperature. Lipase activity of the enzyme was assayed at temperatures ranging from 5 to $75^{\circ} \mathrm{C}$. The substrate emulsions were held at the respective temperature for $5 \mathrm{~min}$ before the addition of the enzyme.

Thermal stability. Portions of the purified lipase were held at temperatures ranging from 50 to $100^{\circ} \mathrm{C}$ for $5 \mathrm{~min}$ in culture tubes. Heating time did not include the time to attain the required temperature. The assay was carried out for each treatment to obtain lipase stability.

Optimum reaction time. Lipase activity of the enzyme was assayed under optimum reaction conditions at incubation times ranging from 2 to $20 \mathrm{~min}$.

Enzyme kinetics. The purified lipase was incubated with various concentrations of tributyrin substrate, and the final substrate concentration ranged from 0.2 to 15 $\mathrm{m} M$. The Michaelis-Menten constant was calculated by the double reciprocal plot of Lineweaver and Burk (1934).

Molecular mass. The molecular mass of the purified lipase was estimated by SDS-PAGE assay. Phosphorylase $\mathrm{B}(97.4 \mathrm{kDa}), \mathrm{BSA}(66.2 \mathrm{kDa})$, ovalbumin $(45 \mathrm{kDa})$, carbonic anhydrase $(31 \mathrm{kDa})$, and soybean trypsin inhibitor $(21.5 \mathrm{kDa})$ were used as molecular mass markers (Bio-Rad Laboratories, Richmond, CA). The SDSPAGE assay was conducted according to the procedure of Laemmli (1970). Samples were loaded on a $10 \%$ polyacrylamide gel containing $0.1 \%$ SDS with stacking gel. Electrophoresis was performed at $30 \mathrm{~m} \AA$ constant cur-

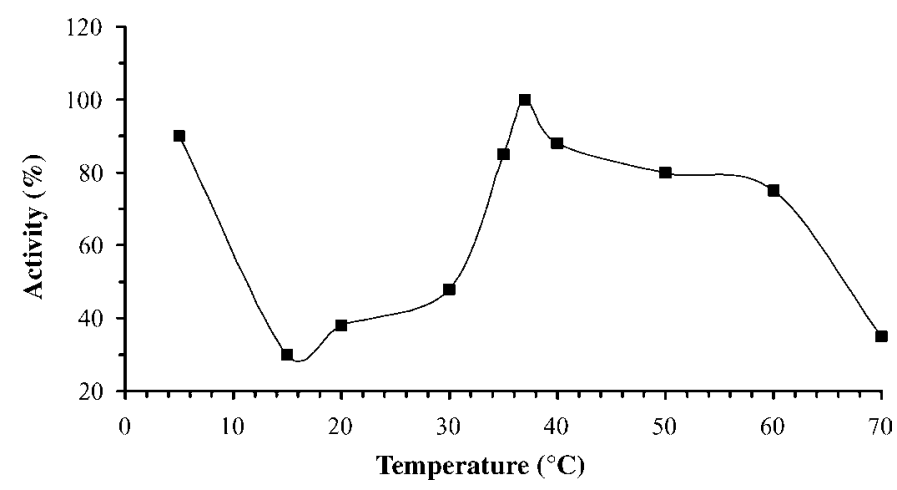

Figure 3. Effect of temperature on the activity of Serratia marcescens purified lipase on $2 \%$ tributyrin at $\mathrm{pH} 8$. 


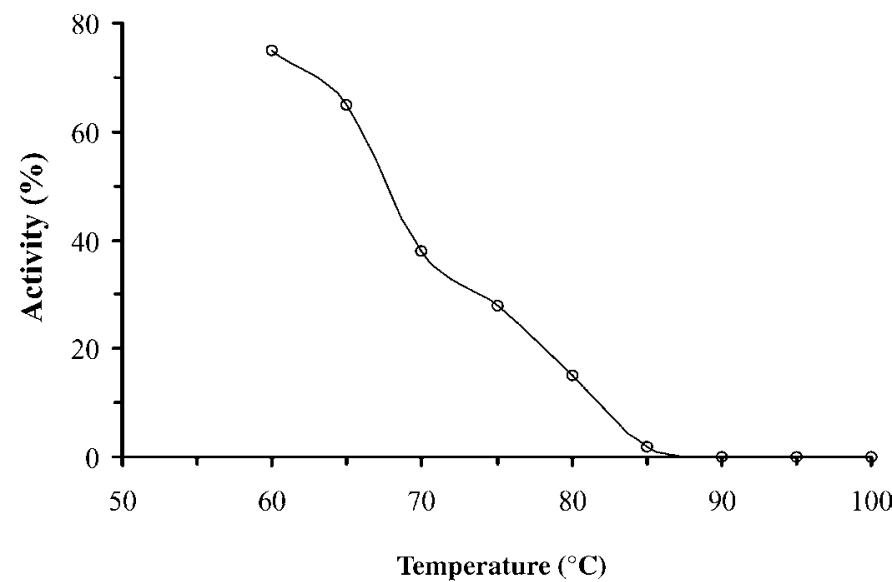

Figure 4. Heat stability curve for Serratia marcescens purified lipase, held at temperature range from 50 to $100{ }^{\circ} \mathrm{C}$ for $5 \mathrm{~min}$.

rent. Gels were stained with silver stain (Wako Pure Chemical Industries, Ltd., Japan).

\section{RESULTS AND DISCUSSION}

\section{Lipolytic Activity of Serratia marcescens on Medium}

The widths of hydrolysis areas were measured to compare the lipolytic activities of $S$. marcescens at different temperatures. At $30^{\circ} \mathrm{C}$, the lipolytic activity of $S$. marcescens appeared after $6 \mathrm{~h}$ with a large discoloration area and the widest area observed after $1.5 \mathrm{~d}$ (Figure 1). At $6^{\circ} \mathrm{C}$, the area of discoloration appeared after 12 $\mathrm{h}$ and increased in width very rapidly and showed its widest area after $6 \mathrm{~d}$. At $17^{\circ} \mathrm{C}$, the activity began after $12 \mathrm{~h}$, but the areas of hydrolysis were smaller than that at $30^{\circ} \mathrm{C}$ and $6^{\circ} \mathrm{C}$. Serratia marcescens showed apparent low activity at $17^{\circ} \mathrm{C}$. The higher activity at $30^{\circ} \mathrm{C}$ may

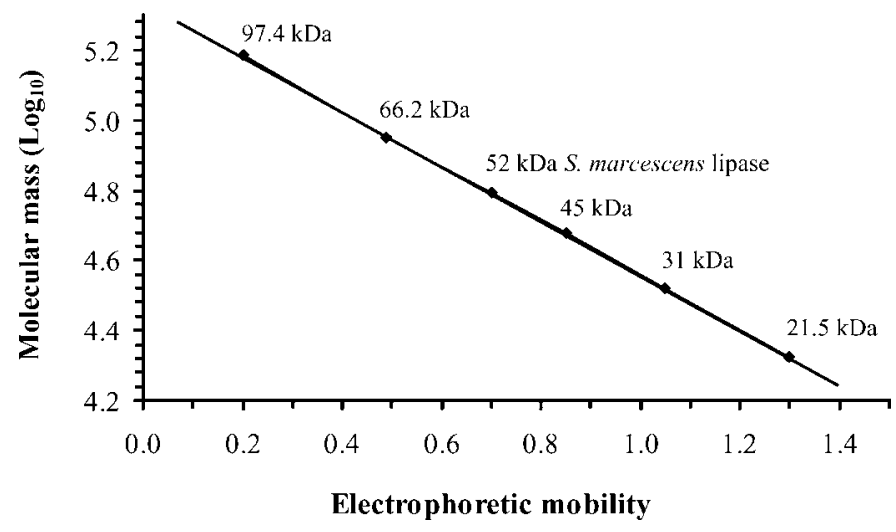

Figure 5. Molecular mass estimation of Serratia marcescens purified lipase by using SDS-PAGE assay. be attributed to maximum growth of the organism and the subsequent increased lipase secretion as it was observed by Makhzoum et al. (1995) during their study of lipase production by $P$. fluorescens. On the other hand, Herbert (1981) reported that many psychrotrophs compensate for growth at low temperature by synthesizing increased quantities of enzymes; Stead (1986) found that lipase production was greatest at $8^{\circ} \mathrm{C}$ for many $P$. fluorescens strains and concluded that increasing the temperature above $8^{\circ} \mathrm{C}$ had a depressing effect on lipase production. Serratia marcescens may have the same pattern of increasing synthesis of lipase at low temperature and depressing production above $8^{\circ} \mathrm{C}$, thus showing activity at $6^{\circ} \mathrm{C}$ higher than that at $17^{\circ} \mathrm{C}$.

\section{Purification of Lipase}

A representative purification profile is summarized in Table 1. On the CM-cellulose column, the highest lipase activity was eluted very early in fractions 6 to 20; specific activity was increased 3.06 -fold, and about $93 \%$ of its activity was recovered. Active fractions were applied to the DEAE-cellulose, and the lipase activity was highest between 0.23 and $0.35 \mathrm{M} \mathrm{NaCl}$ in fractions 21 to 32 . Active fractions, after concentration, were further purified by gel filtration. The purified enzyme was increased by about 20 -fold, and recovery was about $45 \%$. The purified lipase showed only one protein band on SDS-PAGE.

\section{Characterization of the Purified Lipase}

Optimum pH. The optimum $\mathrm{pH}$ was likely between 8 and 9 . The $\mathrm{pH}$ activity curve (Figure 2) showed that the enzyme reached about $73 \%$ of its maximum activity at $\mathrm{pH}$ 6.6. The purified lipase from Serratia grimisii exhibited an optimum $\mathrm{pH}$ over the range 8 to 9 (Abdou, 1997), while that from $S$. marcescens Sr41 8000 showed maximum activity at about $\mathrm{pH} 8$ (Matsumae and Shibatani, 1994). Some previous investigators (Landaas and Solberg, 1978; Adams and Brawley, 1981; Fox and Stepaniak, 1983) showed that the optimum $\mathrm{pH}$ for lipases from different psychrotrophs was 8 , but others (Driessen and Stadhouders, 1974; Law et al., 1976) showed that the $\mathrm{pH}$ optima were 6.5 and 8.75.

pH stability. The purified lipase showed maximal stability at $\mathrm{pH} 8$ (Figure 2). Under $\mathrm{pH}$ 6.6, this lipase lost about $30 \%$ of its activity after holding at $4^{\circ} \mathrm{C}$ for 24 h. Serratia marcescens Sr41 8000 lipase was stable between pH 6 to 9 (Matsumae and Shitatani, 1994); also, that of $S$. grimisii was stable over the $\mathrm{pH}$ range of 7 to 9 (Abdou, 1997). Other lipases showed stability within the $\mathrm{pH}$ range of 5.5 to 9 (Fox and Stepaniak; 1983; Kumura et al., 1993). 
Table 1. Purification of the extracelluar lipase from Serratia mercescens.

\begin{tabular}{llllc}
\hline Purification step & $\begin{array}{l}\text { Total activity } \\
(\mathrm{LU})^{1}\end{array}$ & $\begin{array}{l}\text { Specific activity } \\
(\mathrm{LU} / \mathrm{mg})^{2}\end{array}$ & $\begin{array}{l}\text { Recovered activity } \\
(\%)\end{array}$ & Purity index \\
\hline The crude lipase & 380.6 & 0.107 & 100 & 1 \\
CM-Cellulose & 355.4 & 0.166 & 93.38 & 3.06 \\
DEAE-Cellulose & 192.4 & 1.25 & 50.55 & 12.44 \\
Sephadex G-150 & 172.9 & 1.88 & 45.42 & 20.88 \\
\hline
\end{tabular}

${ }^{1}$ Lipase unit.

${ }^{2}$ Lipase unit/mg protein.

Optimum temperature. The effect of temperature on the lipase activity (Figure 3) showed that optimum temperature for the enzyme was $37^{\circ} \mathrm{C}$, and about $90 \%$ of its maximum activity occurred at $5^{\circ} \mathrm{C}$. That of $S$. grimisii exhibited almost the same activity at low temperature (Abdou, 1997). This high activity at low temperature was observed by some workers; Fox and Stepaniak (1984) found that purified lipase of $P$. fluorescens strain AFT 36 exhibited about $15 \%$ of its maximum activity at $4^{\circ} \mathrm{C}$, Stepaniak et al. (1987) reported that $P$. fluorescens P1 lipase showed about $30 \%$ at $4^{\circ} \mathrm{C}$ and declared that high activities at low temperatures have been found typical characteristics for many lipases from psychrotrophs. Roy (1981) suggested that $S$. marcescens and $P$. fluorescens lipases are probably more stable at low temperartures.

Fox and Stepaniak (1983) concluded that the stability of lipase enzyme for some psychrotrophs over a wide $\mathrm{pH}$ range coupled with its high activity at low temperatures suggest that the enzyme would remain stable for long periods in all dairy products and could have serious implications during their cold storage.

Thermal stability. The lipase of $S$. marcescens showed some stability (Figure 4 ) at $65^{\circ} \mathrm{C}$, but the least residual activity was at $85^{\circ} \mathrm{C}$. It was completely inactivated at $90^{\circ} \mathrm{C}$. S. marcescens lipase is not susceptible to low heat inactivation and is not as thermostable as other lipases from psychrotrophs.

Optimum reaction time. The enzyme reached its maximum activity after 6 min of incubation under optimum reaction conditions (data are not shown).

Enzyme kinetics. Using the double reciprocal plot of Lineweaver and Burk (1934), the enzyme had Michaelis-Menten constant on trybutyrin of $1.35 \mathrm{~m} M$. The enzyme was inhibited by a concentration more than $6.25 \mathrm{~m} M$.

Molecular mass. The molecular mass was estimated to be $52 \mathrm{kDa}$ (Figure 5). Matsumae and Shibatani (1994) found that the molecular mass for $S$. marcescens $\mathrm{Sr} 41$ 8000 lipase was $62 \pm 2 \mathrm{kDa}$, while that of $S$. grimisii was $57 \mathrm{kDa}$ (Abdou, 1997). Lipases from $P$. fluorescens had a molecular mass of 55, 52, $32 \mathrm{kDa}$ (Bozoglu, 1984; Kumura et al., 1993; Stepaniak and Fox, 1985).

\section{REFERENCES}

Abdou, A. M. 1997. Studies on some Gram-negative proteolytic and lipolytic microorganisms in milk and milk products. Ph. D. Diss., Zagazig Univ. (Benha branch), Kaliobyia, Egypt.

Abdou, A. M., and T. Ohashi. 1996. Behavior of lipolytic and proteolytic Gram-negative psychrotrophic bacteria isolated from raw milk, cream and yoghurt in Egypt. Jpn. J. Dairy Food Sci. 45:A97-A104.

Adams, D. M., J. T. Barach, and M. L. Speck. 1975. Heat resistant proteases produced in milk by psychrotrophic bacteria of dairy origin. J. Dairy Sci. 58:828-834.

Adams, D. M., and T. G. Brawley. 1981. Factors influencing the activity of a heat-resistant lipase of Pseudomonas. J. Food Sci. 46:677-680.

Ahmed, M. E., L. Ali, and H. H. A. Khalaf. 1989. Incidence of lipolytic and proteolytic psychrotrophic bacteria in refrigerated raw milk samples. Egypt. J. Vet. Sci. 26:175-180.

Alichanidis, E. 1988. Partial purification and characterization of an extracellular proteinase from Aeromonas hydrophila strain A4. J. Dairy Res. 55:97-107.

Bozoglu, F. 1984. Isolation and characterization of an extracellular heat-stable lipase produced by Pseudomonas fluorescens MC50. Agric. Food. Chem. 32:2-6.

Bradford, M. M. 1976. A rapid and sensitive method for the quantitation of microgram quantities of protein utilizing the principle of protein-dye binding. Anal. Biochem. 72:248-254.

Cousin, M. A. 1982. Presence and activity of psychrotrophic microorganisms in milk and dairy products: a review. J. Food Prot. 45:172-207.

Deeth, H. C., and C. H. Fitzgerald. 1976. Lipolysis in dairy products: a review. Aust. J. Dairy Technol. 31:53-62.

Downey, W. K. 1980. Review of progress of dairy science: flavor impairment from pre- and post-manufacture lipolysis in milk and dairy products. J. Dairy Res. 47:237-252.

Driessen, F. M., and J. Stadhouders. 1974. Thermal activation and inactivation of exocellular lipases of some Gram negative bacteria common in milk. Neth. Milk Dairy J. 28:10-12.

Fairbairn, J. D., and B. A. Law. 1986. Proteineases of psychrotrophic bacteria: their production, properties, effects and control. J. Dairy Res. 53:139-177.

Fox, P. F., and L. Stepaniak. 1983. Isolation and some properties of extracellular heat-stable lipases from Pseudomonas fluorescens strain AFT 36. J. Dairy Res. 50:77-89.

Garcia, M. L., B. Sanz, P. Garcia-Collia, and J. A. Ordonez. 1989. Activity and thermostability of the extracellular lipases and proteinases from pseudomonads isolated from raw milk. Milchwissenschaft 44:547-550.

Griffiths, M. W., G.D. Phillips, and D. D. Muir. 1981. Thermostability of proteases and lipases from a number of species of psychrotrophic bacteria of dairy origin. J. Appl. Bacteriol. 50:289-303.

Henrientte, C., S. Zinebi, M. F. Aumaitre, E. Petitdemange, and H. Petitdemange. 1993. Protease and lipase production by a strain of Serratia marcescens (532 S). J. Ind. Microbiol. 12:129-135.

Herbert, R. A. 1981. A comparative study of the physiology of psychrotrophic and psychrophilic bacteria. Page 3 in Psychrotrophic Microorganisms in Spoilage and Pathogenicity. T. A. Roberts, G. 
Hobbs, J. H. B. Christian, and N. Skovgaard, ed. Academic Press, London, England.

Kumura, H., K. Mikawa, and Z. Saito. 1991. Influence of concomitant protease on the thermostability of lipase of psychrotrophic bacteria. Milchwissenschaft 46:144-149.

Kumura, H., K. Mikawa, and Z. Saito. 1993. Purification and characterization of lipase from Pseudomonas fluorescens No. 33. Milchwissenschaft 48:431-434.

Laemmli, U. K. 1970. Cleavage of structural proteins during the assembly of the head of bacteriophage T4. Nature (Lond.) 227:680-685.

Landaas, A., and P. Solberg. 1978. Production and characterization of lipase from a fluorescent pseudomonad. 20th Int. Dairy Congr., Paris E:304-305.

Law, B. A., M. W. Sharpe, and H. R. Chapman. 1976. The effect of lipolytic Gram negative psychrotrophs in stored milk on the development of rancidity in Cheddar cheese. J. Dairy Res. 43:459-468.

Lineweaver, H., and D. Burk. 1934. The determination of enzyme dissociation constants. J. Am. Chem. Soc. 56:658-662.

Makhzoum, A., J. S. Knapp, and R. K. Owusu. 1995. Factors affecting growth and extracellular lipase production by Pseudomonas fluorescens 2D. Food Microbiol. 12:277-299.

Marshall, R. T., ed. 1992. Standard Methods for the Examination of Dairy Products. 16th ed. Am. Publ. Health Assoc., Washington, DC.

Matsumae, H., and T. Shibatani. 1994. Purification and characterization of the lipase from Serratia marcescens Sr41 8000 responsible for asymmetric hydrolysis of 3-phenylglycidic acid esters. J. Ferment. Bioeng. 77:152-158.

Mikolajcik, E. M. 1979. Psychrotrophic bacteria and dairy product quality. 1. Major organisms involved and defects produced. Cult. Dairy Prod. J. 14:6-10.
Milliere, J. B., and L. Veillet-Poncet, 1985. Flavobacterium, a psychrotrophic, caseolytic bacterium in raw milk. Sci. Aliments. 5:17-20.

Ray, B. 1996. Fundamental Food Microbiology. CRC Press Inc., New York.

Roy, R. N. 1981. A study of the properties, by gel filtration, of the extracellular lipase enzymes of the psychrotrophic bacteria Pseudomonas fluorescens and Serratia marcescens. Page 17 in Psychrotrophic Microorganisms in Spoilage and Pathogenicity. T. A. Roberts, G. Hobbs, J. H. B. Christian, and N. Skovgaard, ed. Academic Press, London, England.

Saito, Z. 1979. Application of the phenol-red method for investigations on the lipolysis of raw milk. Jpn. J. Zootech. Sci. 50:710-715.

Shah, N. P. 1994. Psychrotrphs in milk: A review. Milchwissenschaft 49:432-437.

Stauffer, C. E. 1989. Enzyme Assays for Food Scientists. Van Nostrand Reinhold, New York, NY.

Stead, D. 1986. Microbial lipases: their characteristics, role in food spoilage and industrial uses. J. Dairy Res. 53:481-505.

Stepaniak, L., and P. F. Fox. 1985. Isolation and characterization of heat stable proteineases from Pseudomonas fluorescens strain AFT 21. J. Dairy Res. 52:77-89.

Stepaniak, L., S. E. Brikeland, T. Sorhaug, and G. Vagias. 1987. Isolation and partial characterization of heat stable proteinease, lipase and phospholipase C from Pseudomonas fluorescens P1. Milchwissenschaft 42:75-79.

Thomas, S. B. 1958. Psychrophilic microorganisms in milk and dairy products. Part I. Dairy Sci. Abstr. 20:355-370.

Thomas, S. B., and B. F. Thomas. 1973. Psychrotrophic bacteria in refrigerated bulk-collected raw milk. Part II. Dairy Ind. 38:61-70.

Witter, L. D. 1961. Psychrophilic bacteria. A review. J. Dairy Sci. 44:983-1015 